\title{
Exploring architectures displaying multimeric presentations of a trihydroxypiperidine iminosugar
}

\author{
Camilla Matassini ${ }^{1}$, Stefania Mirabella ${ }^{1}$, Andrea Goti ${ }^{1}$, Inmaculada Robina ${ }^{2}$, \\ Antonio J. Moreno-Vargas ${ }^{2}$ and Francesca Cardona*1
}

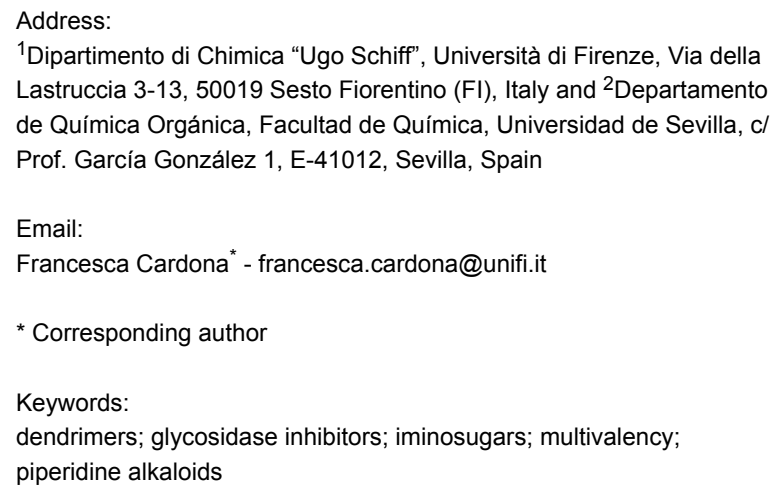

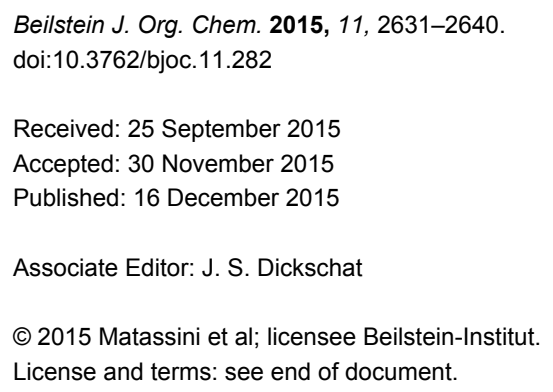

\begin{abstract}
The synthesis of new multivalent architectures based on a trihydroxypiperidine $\alpha$-fucosidase inhibitor is reported herein. Tetravalent and nonavalent dendrimers were obtained by means of the click chemistry approach involving the copper azide-alkynecatalyzed cycloaddition (CuAAC) between suitable scaffolds bearing terminal alkyne moieties and an azido-functionalized piperidine as the bioactive moiety. A preliminary biological investigation is also reported towards commercially available and human glycosidases.
\end{abstract}

\section{Introduction}

Iminosugars are well-known naturally occurring glycomimetics with a nitrogen atom replacing the endocyclic oxygen, mainly recognized as inhibitors of carbohydrate-processing enzymes (glycosidases) [1,2]. In quite sharp contrast the multivalent effect, widely investigated in the field of carbohydrate-lectin interactions [3], has remained essentially unexplored concerning glycosidase inhibition up to 2010. Indeed, the first examples of multivalent iminosugars gave disappointing results in terms of inhibition and therefore were not encouraging [4-6]. However, following the first promising affinity enhancements reported towards jack-bean $\alpha$-mannosidase for a trivalent derivative of 1-deoxynojirimycin [7], over the past six years the multivalent effect in glycosidase inhibition has received an increasing attention by the scientific community, rapidly emerging as a hot topic in glycoscience. Three excellent recent reviews collect the efforts of the researchers both in the synthesis and in the biological evaluation of the new multivalent structures [8-10]. In particular, remarkable high multivalent effects towards jack-bean $\alpha$-mannosidase were reported for fullerene- [11], cyclodextrin- [12,13] and porphyrin- [14] based scaffolds decorated with 1-deoxynojirimycin (DNJ) or 1-deoxymannojirimycin as the bioactive iminosugars. Self-assembled 
DNJ-based glycopeptides also experienced a remarkable multivalent effect towards jack bean $\alpha$-mannosidase [15].

Some mechanisms of action have been also proposed based on the efforts recently devoted to understand the multivalent glycosidase inhibition interactions [10]. Furthermore, some applications of these multivalent systems have been reported involving other glycosidases of therapeutic interest, in particular in the field of rare genetic diseases connected to misfolded proteins [16-18].

While deoxynojrimycin (DNJ) is commonly employed to build diversified multivalent architectures, relative few examples have been reported with different bioactive molecules (namely pyrrolidine- and pyrrolizidine-based iminosugars) [19-21].

Moreover, trivalent pyrrolidine derivatives have been recently employed to probe the multivalent effect towards $\alpha$-L-fucosidase inhibition [22], which may be clinically relevant in the treatment of fucosidosis metabolic disorder and Helicobacter pylori infection, as well as in the elucidation of the biological role of $\alpha$-L-fucosidase in spermiogenesis and sperm maturation [23].

Following our interest in the synthesis of natural alkaloids and their unnatural analogs we recently developed a straightforward synthetic strategy for the synthesis of diversely functionalized trihydroxypiperidines through double reductive amination of the D-mannose-derived aldehyde 2 (Scheme 1) [24,25].

Among the 1-azasugars accessed with this methodology, our attention was drawn to the enantiomer of natural 3,4,5-trihydroxypiperidine (1), ent-1, which showed good inhibitory activity and excellent selectivity towards commercial bovine kidney [25,26] and other mammalian [27] $\alpha$-L-fucosidases.
Moreover, we recently found that $N$-alkylated trihydroxypiperidine 3 showed some chaperoning activity once incubated with human fibroblasts derived from Gaucher bearing N370/ RecNcil mutations, being able to rescue the residual enzyme activity up to 1.25 fold [28].

These findings, together with the opportunity to easily functionalize the trihydroxypiperidine skeleton with an azido moiety at the terminal $N$-alkyl chain, prompted us to investigate the multimerization of compound ent-1 with the aim of studying its inhibitory activity when the molecule decorates a multivalent scaffold. Herein we report the synthesis of a tetra- and a nonavalent polyhydroxypiperidine iminosugar, by exploiting the $\mathrm{Cu}^{\mathrm{I}}$-catalyzed azide-alkyne cycloadditions (CuAAC) [2932] with two different dendrimeric alkyne scaffolds.

\section{Results and Discussion}

The "masked" dialdehyde intermediate 2 was easily synthesized in four steps and $80 \%$ overall yield from D-mannose without the need of any chromatographic purification, by following a slight modification of the published procedure $[24,33]$. The versatility of our synthetic methodology allows access to differently substituted $N$-alkylated trihydroxypiperidines by simply using the same aldehyde and different amines as the nitrogen source in a double reductive amination strategy $[24,25]$.

In particular, catalytic hydrogenation with $\mathrm{Pd}(\mathrm{OH})_{2} / \mathrm{C}$ in $\mathrm{MeOH}$ followed by reductive amination of the formed dialdehyde intermediate with 3-azidopropyl-1-amine [34] in the presence of $\mathrm{NaBH}_{3} \mathrm{CN}$ and $\mathrm{AcOH}$ allowed access to $\mathrm{N}$-alkylated piperidine 4 in 67\% yield (Scheme 2) [25].

With the key azido intermediate $\mathbf{4}$ in hands, we proceeded with the synthesis of two different scaffolds bearing terminal alkyne

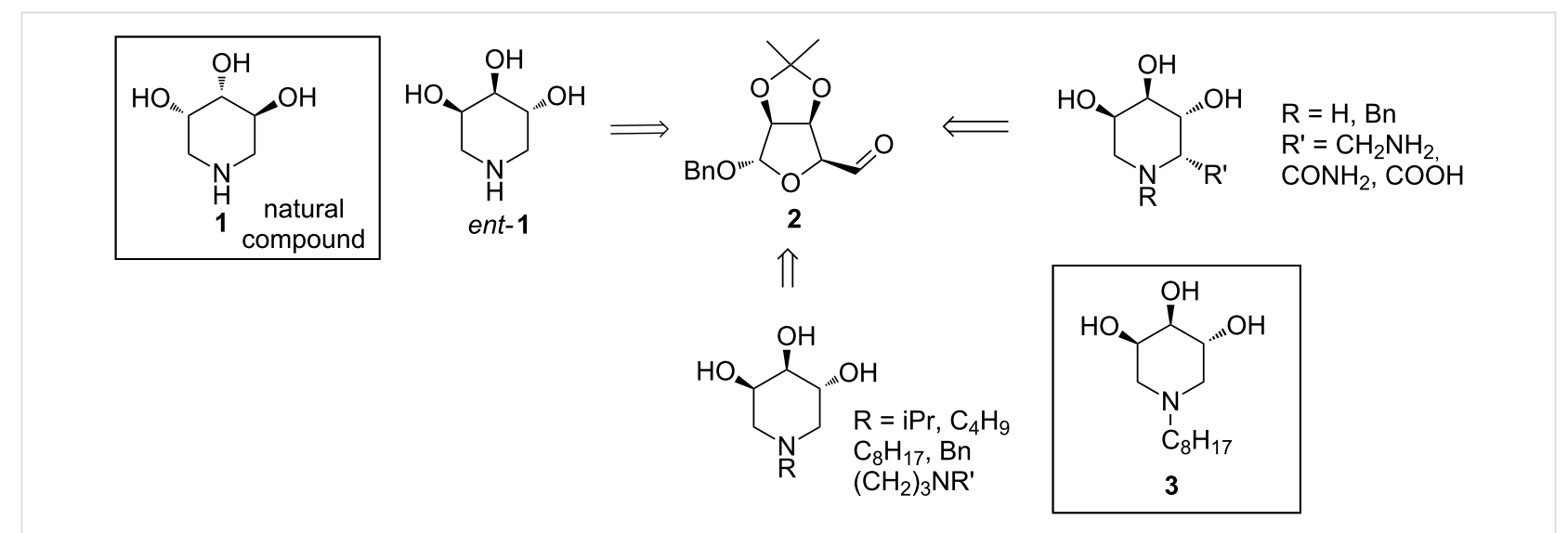

Scheme 1: Double reductive amination on aldehyde 2 allowed the synthesis of trihydroxypiperidines, among which the enantiomer of natural compound 1 and the $\mathrm{N}$-alkylated piperidine 3 . 
<smiles>OC[C@H]1O[C@H](O)[C@@H](O)[C@H](O)[C@H]1O</smiles>

D-mannose

ref. [25]

1. $\mathrm{Pd}(\mathrm{OH})_{2} / \mathrm{C}, \mathrm{H}_{2}, \mathrm{MeOH}$

2. $\mathrm{N}_{3}\left(\mathrm{CH}_{2}\right)_{3} \mathrm{NH}_{2}, \mathrm{MeOH}, 3 \AA \mathrm{MS}$, $\mathrm{NaBH}_{3} \mathrm{CN}, \mathrm{AcOH}$

$67 \%$ over 2 steps

Scheme 2: Synthesis of key azide intermediate 4 through the double reductive amination strategy from "masked" dialdehyde intermediate 2 .

moieties suitable for conjugation to compound 4. A preliminary evaluation of the role of the valency in enhancing the inhibitory activity of the iminosugar was investigated by synthesizing a tetravalent and a nonavalent scaffold. The tetravalent scaffold $\mathbf{5}$ (Scheme 3) was obtained by propargylation of pentaerythritol with propargyl bromide and $\mathrm{NaH}$ following a previously published procedure [35], while the dendrimeric nonavalent scaffold 6 (Scheme 3) was obtained in good yield from the reaction of tris[(propargyloxy)methyl]aminomethane with trimesoyl chloride, as we recently reported [21].

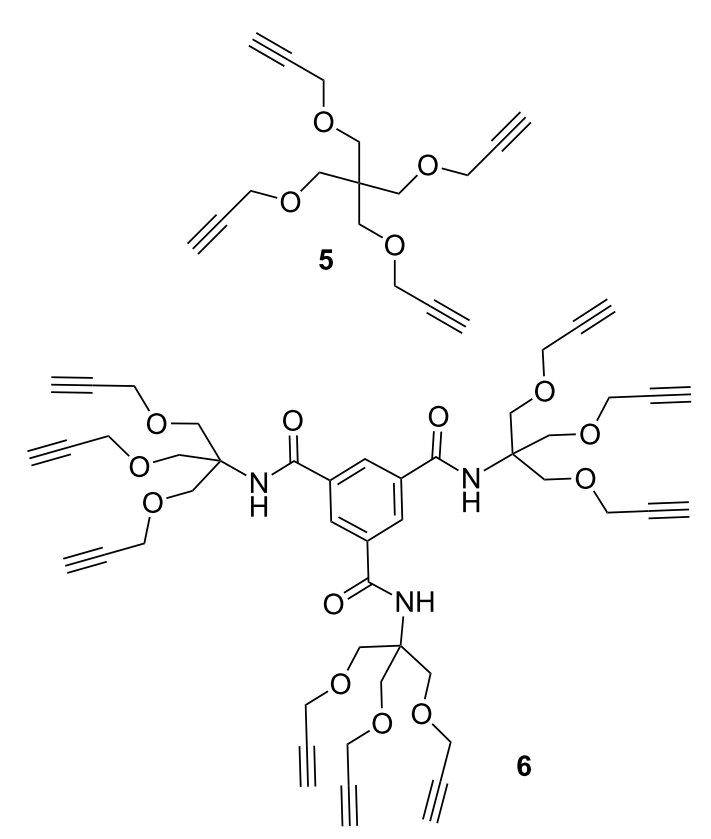

Scheme 3: Tetravalent and nonavalent alkyne scaffolds.

The CuAAC reaction of the azido derivative 4 (4.0 equivalents) with scaffold 5 was performed with $\mathrm{CuSO}_{4} /$ sodium ascorbate in
$\mathrm{THF} / \mathrm{H}_{2} \mathrm{O} 2: 1$ in a $\mathrm{MW}$ reactor at $80{ }^{\circ} \mathrm{C}$ for 45 minutes, affording the expected tetravalent iminosugar derivative 7 in $88 \%$ yield after flash column chromatography (Scheme 4).

Subsequent treatment of 7 in acidic $\mathrm{MeOH}$ at room temperature for 18 hours gave the hydrochloride salt 8 (Scheme 4), which was passed through ion exchange resin Dowex 50WX8-200 eluting successively with $\mathrm{MeOH}, \mathrm{H}_{2} \mathrm{O}$ and $6 \% \mathrm{NH}_{4} \mathrm{OH}$. This general purification procedure, successfully employed by us for several deprotected monovalent compounds [25], resulted much less efficient with the more basic and hydrophilic adduct $\mathbf{8}$. Since in this case most of the compound was recovered in the first fraction with $\mathrm{MeOH}$ as hydrochloride salt and only a small amount in the $\mathrm{NH}_{4} \mathrm{OH}$ final fraction as free amine, we were forced to turn to a protection/deprotection methodology. Hence, the methanolic fraction was acetylated by treatment with excess of pyridine and acetic anhydride, affording compound 9 with 91\% yield after flash column chromatography. After treatment with strongly basic resin Ambersep 900-OH, compound 8 was obtained pure in $86 \%$ yield (Scheme 4 ). This compound and the free amine previously recovered by DOWEX elution of $\mathbf{8} \cdot \mathrm{HCl}$ with $6 \% \mathrm{NH}_{4} \mathrm{OH}$ were proved to be identical by ${ }^{1} \mathrm{H}$ NMR analysis.

To address the synthesis of the nonavalent compound avoiding purification problems we first tried the deprotection of the acetonide groups prior to $\mathrm{CuAAC}$ reaction. Compound $\mathbf{4}$ was treated with $1 \mathrm{M} \mathrm{HCl}$ in $\mathrm{MeOH}$ at room temperature for 16 hours and then passed through Dowex 50WX8-200, following the general purification procedure previously described, to obtain the polyhydroxylated azido derivative $\mathbf{1 0}$ [25] in $90 \%$ yield. The CuAAC reaction of compound $\mathbf{1 0}$ (9 equiv) with the nonavalent alkyne scaffold $\mathbf{6}$, performed with $\mathrm{CuSO}_{4} /$ sodium ascorbate in $\mathrm{THF} / \mathrm{H}_{2} \mathrm{O} 2: 1$ heating in a $\mathrm{MW}$ reactor at $80{ }^{\circ} \mathrm{C}$ for 90 minutes, gave the nonavalent compound 11 in $23 \%$ yield, after flash column chromatography (Scheme 5). The low yield observed for the click reaction of the deprotected azido derivative $\mathbf{1 0}$ can be ascribed to the tricky purification of $\mathbf{1 1}$ that was recovered from silica gel only by eluting with $33 \% \mathrm{NH}_{4} \mathrm{OH}$ due to its high basicity (see Experimental section).

For this reason we decided to change the strategy by performing the click reaction on the protected azido derivative 4 , analogously to what reported with the tetravalent scaffold $\mathbf{5}$. Reaction of 4 (9 equiv) with the nonavalent alkyne scaffold 6 gave compound 12 in excellent $92 \%$ yield (Scheme 5). After treatment in acidic methanol at room temperature for $16 \mathrm{~h}$, the hydrochloride salt of the nonavalent adduct $\mathbf{1 1}$ was obtained in quantitative yield. However, due to the purification problems previously encountered for free amine 11, we decided to purify 
<smiles>CC(C)(C)CN1CC(O)C2OC(C)(C)OC2C1</smiles>

5 (1 equiv)

$\mathrm{CuSO}_{4}$ sodium ascorbate

$\mathrm{THF} / \mathrm{H}_{2} \mathrm{O} 2: 1$, $\mathrm{MW}, 80^{\circ} \mathrm{C}$ $45 \min , 88 \%$

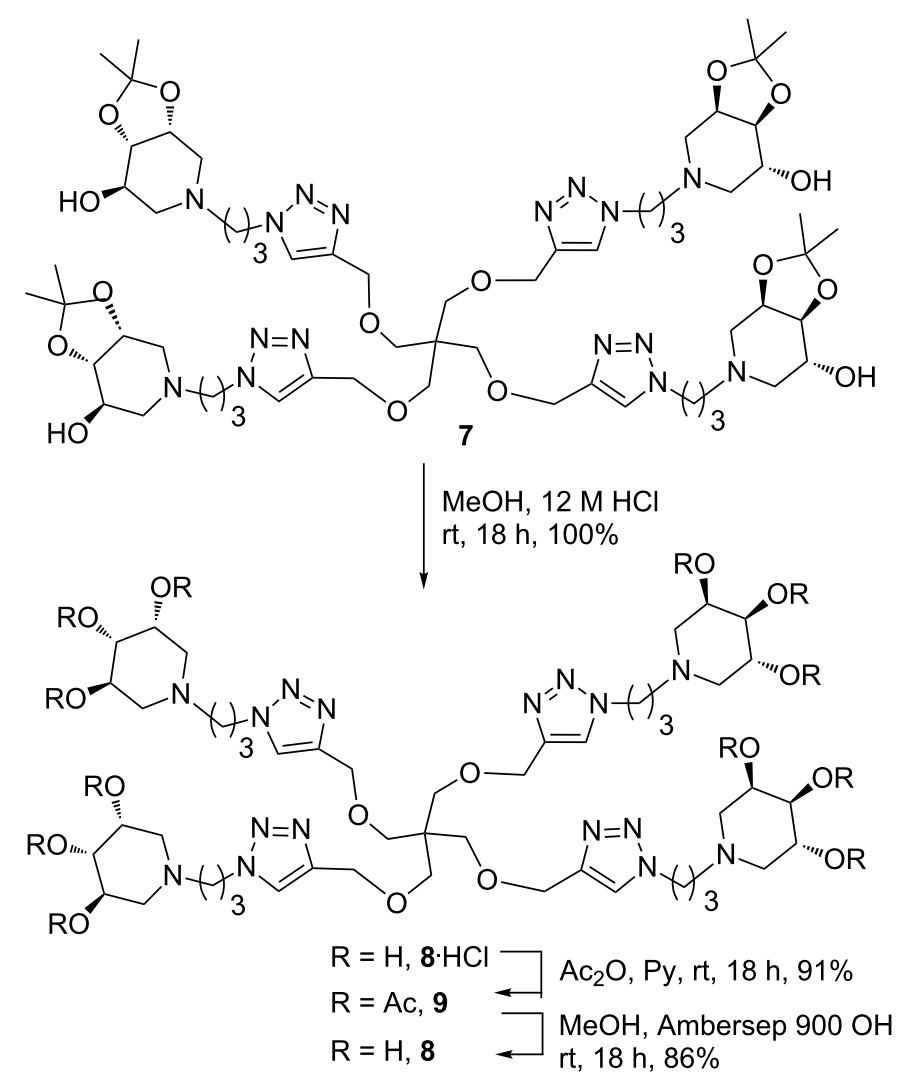

Scheme 4: Synthesis of the tetravalent adduct 7 by CuAAC reaction and its deprotection/purification process to obtain the final compound 8 .

the nonavalent derivative $11 \cdot \mathrm{HCl}$ by size exclusion chromatography. Indeed, in this case, the use of the strongly basic resin Ambersep 900-OH is hampered by the presence of the amidic bonds in compound 11, which are not stable to strong basic conditions. Therefore, $\mathbf{1 1} \cdot \mathrm{HCl}$ was quickly passed over Sephadex LH-20 resin, eluted with water, to obtain the purified compound as hydrochloride salt, which was thus employed in further biological evaluation.

In order to evaluate the relative inhibitory activity enhancement of these new multimeric systems, a proper monovalent counterpart was also synthesized. In particular, starting from azidopiperidine 4 , the $\mathrm{CuAAC}$ reaction was performed with propargylamine (13) in the presence of $\mathrm{CuSO}_{4} /$ sodium ascorbate in $\mathrm{THF} / \mathrm{H}_{2} \mathrm{O} 2: 1$ at room temperature affording adduct $\mathbf{1 4}$ in $96 \%$ yield (Scheme 6 ). Final deprotection by treatment with $\mathrm{MeOH} / \mathrm{HCl}$ and eluting over ion exchange resin Dowex 50WX8-200, afforded the monovalent compound $\mathbf{1 5}$ in $77 \%$ yield.

Searching for a multivalent effect towards $\alpha$-fucosidase inhibition, the tetravalent compound $\mathbf{8}$, the nonavalent compound $11 \cdot \mathrm{HCl}$, as well as the monovalent $\mathbf{1 5}$, were assayed as glycosidase inhibitors towards $\alpha$-fucosidase (EC 3.2.1.51) from bovine kidney. Eight further commercially available glycosidases were also considered in order to investigate a possible change in selectivity due to the polyhydroxypiperidine multimerization. The results are summarized in Table 1, where inhibition of simple 3,4,5-trihydroxypiperidine ent-1 is also reported for sake of completeness.

Unfortunately, concerning the $\alpha$-fucosidase inhibition, the multimerization of active polyhydroxypiperidine ent-1 onto both tetravalent and nonavalent scaffolds $(\mathbf{8}$ and $\mathbf{1 1} \cdot \mathrm{HCl})$, as well as the simple functionalization at the nitrogen atom (15) led to a dramatic decrease of its inhibitory activity, demonstrating a low tendency of this enzyme to be influenced by multivalent presentation [22]. Conversely, some effect in the change of selectivity can be observed as attested by the increase on amyloglucosidase inhibition. In this case, while ent-1 does not inhibit this enzyme at all, increasing inhibitory activity was observed passing from its tetravalent derivative (57\%) to the nonavalent $(86 \%)$ one. For this latter compound $(\mathbf{1 1} \cdot \mathrm{HCl})$, $\mathrm{IC}_{50}=179 \mu \mathrm{M}$ was calculated [36]. This outcome is particularly desirable with multimeric iminosugars for increasing the overall binding affinity of weak inhibitors, as recently pointed out by Winum and Ulrich in a recent review [37]. It should also be noted that analogous changes in selectivity towards different 

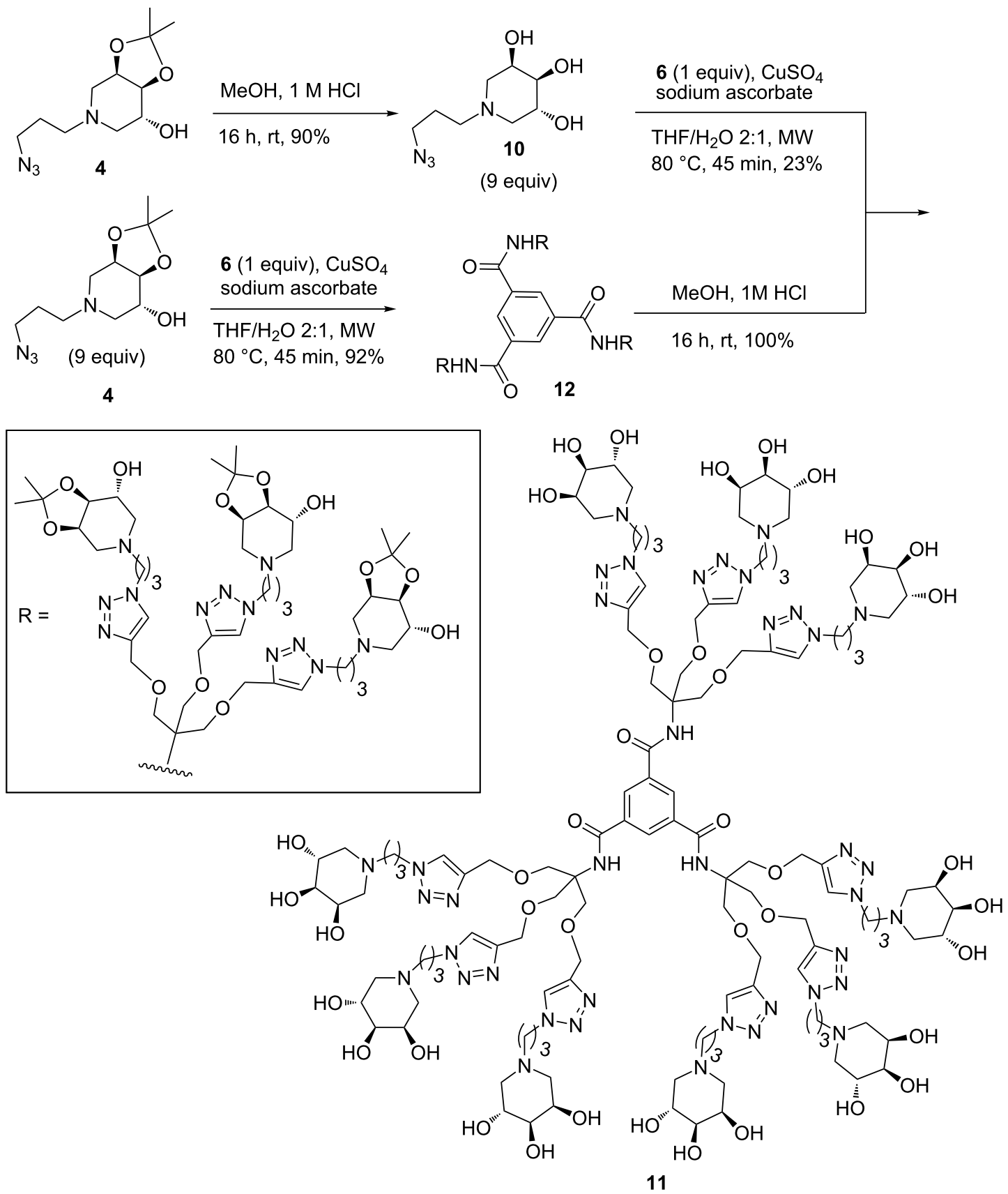

Scheme 5: Synthesis of nonavalent adduct 11 by CuAAC reaction and its deprotection.

glycosidases comparing monovalent with multivalent polymeric iminosugars were recently documented [38].

However, by comparing the $\mathrm{IC}_{50}$ value of $\mathbf{1 1} \cdot \mathrm{HCl}$ with the monovalent counterpart $\mathbf{1 5}$ (relative inhibition potency $=6$ ), an effective multivalent effect cannot be claimed, since the enhancement observed is not higher than 9-fold (the valency of the dendrimeric compound).
Since in our experience the inhibition data towards commercial and human glycosidases do not always match [28], we then decided to evaluate the most promising nonavalent compound $\mathbf{1 1} \cdot \mathrm{HCl}$ also towards human glycosidases. In particular, compound $11 \cdot \mathrm{HCl}$ was incubated at $1 \mathrm{mM}$ in an extract from a pool of leukocytes isolated from healthy donors and the $\alpha$-fucosidase activity was estimated by fluorescence measurements. A $46 \%$ inhibitory activity, calculated with respect to the blank 
<smiles>C#CCNCCCn1cc(CN)nn1</smiles>

1) $\mathrm{MeOH}, \mathrm{HCl} 1 \mathrm{M}$ rt, $16 \mathrm{~h}$

2) Dowex 50WX8-200 $77 \%$<smiles>NCc1cn(CCCN2C[C@H](O)[C@H](O)[C@H](O)C2)nn1</smiles>

Scheme 6: Synthesis of the monovalent iminosugar 15 by CuAAC reaction and subsequent deprotection of the hydroxy groups.

control, was found: this data is in complete agreement with the value obtained towards the commercial glycosidase. We finally evaluated $11 \cdot \mathrm{HCl}$ against two lysosomal enzymes, $\mathrm{N}$-acetylgalactosamine-6-sulfate sulfatase (GALNS) and iduronate 2-sulfatase that, being dimers [39], are in principle more prone to accept multivalent substrates. Actually only low inhibition activities (50\% and 69\%, respectively) were measured for these two enzymes, that represent appealing targets for the treatment of rare metabolic disorders such as mucopolysaccharidosis type IVA (Morquio A) and mucopolysaccharidosis type II (Hunter syndrome).

\section{Conclusion}

In conclusion, the synthesis of two new dendrimeric iminosugars (namely a tetravalent and a nonavalent) based on a trihydroxypiperidine $\alpha$-fucosidase inhibitor was achieved in this work. Based on a key trihydroxypiperidine intermediate bearing a terminal azido moiety, the CuAAC approach was investigated either on the protected and deprotected iminosugar, with different purification techniques employed in both cases. A monomer reference compound was also synthesized for comparison. Biological evaluation against a panel of eleven commercially available glycosidases showed that fucosidase inhibition is lost, while an unexpected amyloglucosidase inhibition is observed with these dendrimeric compounds. Moreover, preliminary evaluation towards human glycosidases showed moderate inhibition towards particularly relevant enzymes, so there is clearly space to consider expansion of our current amyloglucosidase inhibitors so as to generate therapeutically significant and specific inhibitors.

\begin{tabular}{|c|c|c|c|c|}
\hline \multirow[t]{2}{*}{ Commercially available glycosidases } & \multicolumn{4}{|c|}{ Evaluated compounds } \\
\hline & ent-1 & 8 & $11 \cdot \mathrm{HCl}$ & 15 \\
\hline $\begin{array}{l}\alpha \text {-L-fucosidase } \\
\text { bovine kidney }\end{array}$ & $\begin{array}{l}89[25] \\
(90.3)\end{array}$ & 45 & 41 & 28 \\
\hline $\begin{array}{l}\alpha \text {-galactosidase } \\
\text { coffee beans }\end{array}$ & - & 39 & 58 & - \\
\hline $\begin{array}{l}\text { } \beta \text {-galactosidase } \\
\text { Escherichia coli } \\
\text { Aspergillus oryzae }\end{array}$ & - & - & - & - \\
\hline $\begin{array}{l}\text { a-glucosidase } \\
\text { Saccharomyces cerevisiae } \\
\text { rice }\end{array}$ & - & 29 & - & - \\
\hline $\begin{array}{l}\text { amyloglucosidase } \\
\text { Aspergillus niger }\end{array}$ & - & 57 & $\begin{array}{l}86 \\
(179)\end{array}$ & $\begin{array}{l}45 \\
(1100)\end{array}$ \\
\hline $\begin{array}{l}\beta \text {-glucosidase } \\
\text { almonds }\end{array}$ & - & - & - & - \\
\hline $\begin{array}{l}\alpha-\text {-mannosidase } \\
\text { jack beans }\end{array}$ & - & - & 32 & - \\
\hline $\begin{array}{l}\beta \text {-mannosidase } \\
\text { snail }\end{array}$ & - & - & - & - \\
\hline $\begin{array}{l}\boldsymbol{\beta}-\boldsymbol{N} \text {-acetylglucosaminidase } \\
\text { jack beans }\end{array}$ & - & - & - & - \\
\hline
\end{tabular}

- : no inhibition was detected at $1 \mathrm{mM}$ concentration of the corresponding compound. 


\section{Experimental}

General methods: Commercial reagents were used as received. All reactions were carried out under magnetic stirring and monitored by TLC on $0.25 \mathrm{~mm}$ silica gel plates (Merck $\mathrm{F}_{254}$ ). Column chromatographies were carried out on Silica Gel 60 $(32-63 \mu \mathrm{m})$ or on silica gel (230-400 mesh, Merck). Yields refer to spectroscopically and analytically pure compounds unless otherwise stated. ${ }^{1} \mathrm{H}$ NMR spectra were recorded on a Varian Mercury-400 or on a Varian INOVA 400 instruments at $25{ }^{\circ} \mathrm{C} .{ }^{13} \mathrm{C}$ NMR spectra were recorded on a Varian Gemini200 or on a Varian Gemini-300 spectrometer. Chemical shifts are reported relative to TMS $\left({ }^{1} \mathrm{H}: \delta=0.00 \mathrm{ppm}\right)$ and $\mathrm{CDCl}_{3}$ $\left({ }^{13} \mathrm{C}: \delta=77.0 \mathrm{ppm}\right)$. Integrals are in accordance with assignments, coupling constants are given in Hz. For detailed peak assignments 2D spectra were measured (COSY, HSQC, NOESY, and NOE as necessary). Small scale microwaveassisted syntheses were carried out in a microwave apparatus for synthesis (CEM Discover) with an open reaction vessel and external surface sensor. IR spectra were recorded with a BX FTIR Perkin-Elmer system spectrophotometer. ESIMS spectra were recorded with a Thermo Scientific ${ }^{\mathrm{TM}}$ LCQ fleet ion trap mass spectrometer. Elemental analyses were performed with a Perkin-Elmer 2400 analyzer. Optical rotation measurements were performed on a JASCO DIP-370 polarimeter.

Protected tetravalent iminosugar 7: In a similar manner as described in [21] to a solution of $4(89 \mathrm{mg}, 0.35 \mathrm{mmol})$ in $1.8 \mathrm{~mL}$ of a $2: 1 \mathrm{THF} / \mathrm{H}_{2} \mathrm{O}$ mixture, $\mathrm{CuSO}_{4}(30 \mathrm{~mol} \%, 3.8 \mathrm{mg}$, $0.024 \mathrm{mmol})$, sodium ascorbate $(60 \mathrm{~mol} \%, 9.5 \mathrm{mg}$, $0.048 \mathrm{mmol}$ ) and $5(23 \mathrm{mg}, 0.08 \mathrm{mmol})$ were added. The reaction mixture was heated in a MW reactor at $80^{\circ} \mathrm{C}$ for $45 \mathrm{~min}$, until TLC analysis showed the disappearance of the starting material. After filtration through Celite ${ }^{\circledR}$, the solvent was removed under reduced pressure and the crude product was purified by gradient $\mathrm{FCC}$ (from $\mathrm{CH}_{2} \mathrm{Cl}_{2} / \mathrm{MeOH}$ 10:1 to $\mathrm{CH}_{2} \mathrm{Cl}_{2} / \mathrm{MeOH} /$ $\mathrm{NH}_{4} \mathrm{OH} \mathrm{6 \%} \mathrm{10:1:0.1)} \mathrm{affording} \mathrm{pure} 7(92 \mathrm{mg}, 0.07 \mathrm{mmol}$, $88 \%)$ as a pale yellow oil. $R_{\mathrm{f}} 0.32\left(\mathrm{CH}_{2} \mathrm{Cl}_{2} / \mathrm{MeOH} / \mathrm{NH}_{4} \mathrm{OH} 6 \%\right.$ 10:1:0.1); $[\alpha]_{\mathrm{D}}{ }^{24}+4.88\left(\right.$ c $\left.1.92, \mathrm{CHCl}_{3}\right) ;{ }^{1} \mathrm{H} \mathrm{NMR}(400 \mathrm{MHz}$, $\left.\mathrm{CDCl}_{3}\right) \delta 7.67\left(\mathrm{~s}, 4 \mathrm{H}, \mathrm{H}\right.$-triazole), $4.54\left(\mathrm{~s}, 8 \mathrm{H}, \mathrm{OCH}_{2}\right.$-triazole), 4.44 (t, $J=6.6 \mathrm{~Hz}, 8 \mathrm{H}, 3$ '-H), 4.32 (dd, $J=11.7,5.3 \mathrm{~Hz}, 4 \mathrm{H}$, 3-H), 4.05 (t, $J=4.7 \mathrm{~Hz}, 4 \mathrm{H}, 4-\mathrm{H}), 3.98-3.95$ (m, 4H, 5-H), $3.42\left(\mathrm{~s}, 8 \mathrm{H}, \mathrm{CCH}_{2} \mathrm{O}\right), 2.71(\mathrm{dd}, J=12.0,5.3 \mathrm{~Hz}, 4 \mathrm{H}, 2-\mathrm{Ha})$, 2.59 (dd, $J=11.7,2.9 \mathrm{~Hz}, 4 \mathrm{H}, 6-\mathrm{Ha}), 2.47-2.41$ (m, 8H, 2- $\mathrm{Hb}+$ 6-Hb), 2.36 (t, $\left.J=6.6 \mathrm{~Hz}, 8 \mathrm{H}, 1^{\prime}-\mathrm{H}\right), 2.11-2.03$ (m, 8H, 2'-H), 1.49 (s, 12H, Me), 1.35 (s, 12H, Me) ppm; ${ }^{13} \mathrm{C} \mathrm{NMR} \mathrm{(50} \mathrm{MHz,}$ $\left.\mathrm{CDCl}_{3}\right) \delta 145.1$ (s, 4C, C-triazole), 123.3 (d, 4C, C-triazole), 109,0 (s, 4C, acetal), 77.3 (d, 4C, C-4), 72.2 (d, 4C, C-3), 68.9 (t, $4 \mathrm{C}, \mathrm{CCH}_{2} \mathrm{O}$ ), 68.0 (d, 4C, C-5), 64.8 (t, 4C, OCH 2 -triazole), 56.1 (t, 4C, C-6), 54.8 (t, 4C, C-2), 53.4 (t, 4C, C-1'), 47.7 (t, 4C, C-3'), 45.2 (s, $\mathrm{CCH}_{2} \mathrm{O}$ ), 28.3 (q, 4C, $\mathrm{Me}$ ), 27.3 (t, 4C, C-2'), 26.3 (q, 4C, Me) ppm; MS (ESI) $m / z$ (\%): 1335.83 (100)
$[\mathrm{M}+\mathrm{Na}]^{+} ; \mathrm{IR}\left(\mathrm{CDCl}_{3}\right): v 3629,3416,3143,2988,2939,2826$, 2247, 1724, 1665, 1550, 1468, 1383, 1220, $1058 \mathrm{~cm}^{-1}$; anal. calcd for $\mathrm{C}_{61} \mathrm{H}_{100} \mathrm{~N}_{16} \mathrm{O}_{16}$ : C, 55.78; H, 7.67; N, 17.06; found: C, 55.74; H, 7.66; N, 16.83.

Peracetylated tetravalent iminosugars 9: In a similar manner as described in [21] to a solution of $7(85 \mathrm{mg}, 0.065 \mathrm{mmol})$ in $35 \mathrm{~mL}$ of methanol, $0.22 \mathrm{~mL}$ (10.0 equiv) of $37 \% \mathrm{HCl}$ were added and the mixture was stirred at room temperature for 18 hours. After that a TLC analysis showed the disappearance of the starting material, the solvent was removed under reduced pressure. Successively elution with $\mathrm{MeOH}, \mathrm{H}_{2} \mathrm{O}$ and $6 \%$ $\mathrm{NH}_{4} \mathrm{OH}$ over ion exchange resin Dowex 50WX8-200 afforded $9 \mathrm{mg}(0.008 \mathrm{mmol})$ of corresponding free amine and $42 \mathrm{mg}$ $(0.032 \mathrm{mmol})$ of hydrochloride salt $(\mathrm{MeOH}$ fraction). This fraction was dissolved in pyridine $(1.2 \mathrm{~mL})$ and acetic anhydride $(0.8 \mathrm{~mL})$ was added. The solution was stirred at room temperature for 18 hours. Then, after concentration under reduced pressure, the crude mixture was purified by gradient FCC (from $\mathrm{CH}_{2} \mathrm{Cl}_{2} / \mathrm{MeOH} 20: 1$ to $\left.5: 1\right)$ affording pure $9(48 \mathrm{mg}$, $0.029 \mathrm{mmol}, 91 \%)$ as an oil. $R_{\mathrm{f}} 0.22\left(\mathrm{CH}_{2} \mathrm{Cl}_{2} / \mathrm{MeOH} 10: 1\right)$; $[\alpha]_{\mathrm{D}}{ }^{22}-42.1\left(c 1.45, \mathrm{CHCl}_{3}\right) ;{ }^{1} \mathrm{H} \mathrm{NMR}\left(400 \mathrm{MHz}, \mathrm{CDCl}_{3}\right) \delta$ 7.55 (s, 4H, H-triazole), $5.22(\mathrm{dt}, J=5.4,2.7 \mathrm{~Hz}, 4 \mathrm{H}, 3-\mathrm{H})$, $5.07(\mathrm{dt}, J=8.2,4.4 \mathrm{~Hz}, 4 \mathrm{H}, 5-\mathrm{H}), 4.90(\mathrm{dd}, J=8.8,3.4 \mathrm{~Hz}$, $4 \mathrm{H}, 4-\mathrm{H}), 4.48$ (s, 8H, OCH${ }_{2}$-triazole), 4.42-4.29 (m, 8H, 3'-H), 3.39 (s, 8H, CCH ${ }_{2} \mathrm{O}$ ), 2.92 (d, $\left.J=8.3 \mathrm{~Hz}, 4 \mathrm{H}, 6-\mathrm{Ha}\right)$, 2.77 (dd, $J=12.1,3.9 \mathrm{~Hz}, 4 \mathrm{H}, 2-\mathrm{Ha}), 2.40-2.33$ (m, 12H, 2-Hb + 1'-H), 2.21-2.15 (m, 4H, 6-Hb), 2.03 (s, 12H, Ac), 2.01-1.93 (m, 8H, 2'-H), 1.99 (s, 12H, Ac), 1.97 (s, 12H, Ac) ppm; ${ }^{13} \mathrm{C}$ NMR $\left(50 \mathrm{MHz}, \mathrm{CDCl}_{3}\right) \delta 169.2(\mathrm{~s}, 12 \mathrm{C}, \mathrm{OAc}), 144.3(\mathrm{~s}$, 4C, C-triazole), 122.3 (d, 4C, C-triazole), 70.6 (d, 4C, C-4), 68.9 (t, 4C, $\left.\mathrm{CCH}_{2} \mathrm{O}\right), 67.8$ (d, 4C, C-5), 67.5 (d, 4C, C-3), 64.7 (t, 4C, $\mathrm{OCH}_{2}$-triazole), $53.6(\mathrm{t}, 4 \mathrm{C}, \mathrm{C}-2), 53.2(\mathrm{t}, 4 \mathrm{C}, \mathrm{C}-6), 53.0$ (t, 4C, C-1'), 47.4 (t, 4C, C-3'), 45.3 (s, $\mathrm{CCH}_{2} \mathrm{O}$ ), 27.2 (t, 4C, C-2'), 20.8-20.5 (q, 12C, OAc) ppm; MS (ESI) $\mathrm{m} / \mathrm{z}(\%)$ : $1679.92(100)[\mathrm{M}+\mathrm{Na}]^{+}$; IR $\left(\mathrm{CDCl}_{3}\right): v 3451,3145,2960$, 2874, 2825, 2258, 2246, 1743, 1663, 1470, 1437, 1372, 1231, $1049 \mathrm{~cm}^{-1}$; anal. calcd for $\mathrm{C}_{73} \mathrm{H}_{108} \mathrm{~N}_{16} \mathrm{O}_{28}$ : C, 52.89; $\mathrm{H}, 6.57$; $\mathrm{N}, 13.52$; found: C, 52.52; H, 6.25; N, 13.90 .

Polyhydroxylated tetravalent iminosugar 8: In a similar manner as described in [21] a suspension of 9 (31 mg, $0.019 \mathrm{mmol}$ ) and ion exchange resin Ambersep-900 OH $(500 \mathrm{mg}$ ) in $10 \mathrm{~mL}$ of methanol was slowly stirred at room temperature for $16 \mathrm{~h}$. After filtration of resin on Celite ${ }^{\circledR}$, the solvent was removed under reduced pressure affording pure $\mathbf{8}$ (19 mg, $0.016 \mathrm{mmol}, 86 \%$ yield) as a waxy solid. $[\alpha]_{\mathrm{D}}{ }^{23}-13.0$ (c 1.1, $\mathrm{H}_{2} \mathrm{O}$ ); ${ }^{1} \mathrm{H}$ NMR $\left(400 \mathrm{MHz}, \mathrm{D}_{2} \mathrm{O}\right) \delta 7.83$ (s, 4H, H-triazole), 4.38 (s, $8 \mathrm{H}, \mathrm{OCH}_{2}$-triazole), 4.31 (t, $J=6.8 \mathrm{~Hz}, 8 \mathrm{H}$, 3'-H), 3.86-3.82 (m, 4H, 3-H), 3.72 (td, $J=8.8,4.4 \mathrm{~Hz}, 4 \mathrm{H}$, 5-H), 3.58-3.34 (m, 4H, 4-H), $3.25\left(\mathrm{~s}, 8 \mathrm{H}, \mathrm{CCH}_{2} \mathrm{O}\right), 2.72-2.65$ 
$(\mathrm{m}, 8 \mathrm{H}, 2-\mathrm{Ha}+6-\mathrm{Ha}), 2.28-2.11\left(\mathrm{~m}, 12 \mathrm{H}, 2-\mathrm{Hb}+1^{\prime}-\mathrm{H}\right)$, 2.00-1.9 (m, 12H, 6-Hb + 2'-H) ppm; ${ }^{13} \mathrm{C}$ NMR (50 MHz, $\left.\mathrm{D}_{2} \mathrm{O}\right) \delta 143.2$ (s, 4C, C-triazole), 124.0 (d, 4C, C-triazole), 72.8 (d, 4C, C-4), $67.1\left(\mathrm{t}, 4 \mathrm{C}, \mathrm{CCH}_{2} \mathrm{O}\right), 66.8$ (d, 4C, C-3), 66.6 (d, 4C, C-5), 62.6 (t, 4C, OCH -triazole), 55.7 (t, 4C, C-6), 54.8 (t, $4 \mathrm{C}, \mathrm{C}-2), 52.9$ (t, 4C, C-1'), 47.7 (t, 4C, C-3'), 43.7 (s, $\mathrm{CCH}_{2} \mathrm{O}$ ), 25.4 (t, 4C, C-2') ppm; MS (ESI) $\mathrm{m} / z(\%): 1175.79$ (100) $[\mathrm{M}+\mathrm{Na}]^{+}$; anal. calcd for $\mathrm{C}_{49} \mathrm{H}_{84} \mathrm{~N}_{16} \mathrm{O}_{16}: \mathrm{C} 51.03, \mathrm{H}$ 7.34, N 19.43; found: C, 50.71; H, 7.46; N, 19.62 .

Deprotected nonavalent iminosugar 11: Analogously as described in [21] to a solution of $\mathbf{1 0}(50 \mathrm{mg}, 0.23 \mathrm{mmol})$ in $3 \mathrm{~mL}$ of a $2: 1 \mathrm{THF} / \mathrm{H}_{2} \mathrm{O}$ mixture, $\mathrm{CuSO}_{4}(30 \mathrm{~mol} \%, 1.2 \mathrm{mg}$, $0.007 \mathrm{mmol})$, sodium ascorbate $(80 \mathrm{~mol} \%, 4.1 \mathrm{mg}$, $0.021 \mathrm{mmol})$ and $6(21 \mathrm{mg}, 0.025 \mathrm{mmol})$ were added. The reaction mixture was heated in a MW reactor at $80^{\circ} \mathrm{C}$ for $90 \mathrm{~min}$, until TLC analysis showed the disappearance of the nonavalent alkyne scaffold. After filtration through Celite ${ }^{\circledR}$, the solvent was removed under reduced pressure and the crude product was purified by gradient $\mathrm{FCC}$ (from $\mathrm{CH}_{2} \mathrm{Cl}_{2} / \mathrm{MeOH} / \mathrm{NH}_{4} \mathrm{OH} 6 \%$ 1:1:0.3 to $\mathrm{NH}_{4} \mathrm{OH} 33 \%$ ) to afford pure $11(16 \mathrm{mg}, 0.006 \mathrm{mmol}$, $23 \%)$ as a pale yellow oil. $R_{\mathrm{f}} 0.19\left(\mathrm{CH}_{2} \mathrm{Cl}_{2} / \mathrm{MeOH} / \mathrm{NH}_{4} \mathrm{OH}\right.$ $33 \% 1: 1: 0.3) ;[\alpha]_{\mathrm{D}}{ }^{21}-21.31\left(c \quad 1.30, \mathrm{H}_{2} \mathrm{O}\right) ;{ }^{1} \mathrm{H}$ NMR (400 MHz, $\left.\mathrm{D}_{2} \mathrm{O}\right) \delta 7.87$ (s, 3H, Ar), 7.82 (s, 9H, H-triazole), 4.45 (s, $18 \mathrm{H}, \mathrm{OCH}_{2}$-triazole), 4.22 (t, $J=6.7 \mathrm{~Hz}, 18 \mathrm{H}, 3$ '-H), $3.82-3.80(\mathrm{~m}, 9 \mathrm{H}, 3-\mathrm{H}), 3.71-3.66(\mathrm{~m}, 27 \mathrm{H}, 5-\mathrm{H}+$ $\left.\mathrm{OCH}_{2} \mathrm{CNH}\right), 3.33-3.29(\mathrm{~m}, 9 \mathrm{H}, 4-\mathrm{H}), 2.72$ (d, $J=9.9 \mathrm{~Hz}, 9 \mathrm{H}$, 6-Ha), 2.66 (d, $J=10.3 \mathrm{~Hz}, 9 \mathrm{H}, 2-\mathrm{Ha}), 2.28-2.23(\mathrm{~m}, 18 \mathrm{H}$, 1'-H), 2.17 (d, $J=10.2 \mathrm{~Hz}, 9 \mathrm{H}, 6-\mathrm{Hb}), 1.96-1.84(\mathrm{~m}, 27 \mathrm{H}$, $\left.2-\mathrm{Hb}+2^{\prime}-\mathrm{H}\right) \mathrm{ppm} ;{ }^{13} \mathrm{C}$ NMR (100 MHz, $\left.\mathrm{D}_{2} \mathrm{O}\right) \delta 168.1$ (s, 3C, $\mathrm{C}=\mathrm{O}$ ), 143.9 (s, 9C, C-triazole), 135.1 (s, 3C, Ar), 129.0 (d, 3C, Ar), 124.9 (d, 9C, C-triazole), 73.2 (d, 9C, C-4), 67.2 (d, 9C, $\mathrm{C}-3), 67.1\left(\mathrm{~d}+\mathrm{t}, 18 \mathrm{C}, \mathrm{C}-5+\mathrm{OCH}_{2} \mathrm{CNH}\right), 63.5\left(\mathrm{t}, 9 \mathrm{C}, \mathrm{OCH}_{2-}\right.$ triazole), 60.7 (s, 3C, $\left.\mathrm{OCH}_{2} \mathrm{CNH}\right), 56.0$ (t, 9C, C-2), 55.3 (t, 9C, C-6), 53.6 (t, 9C, C-1'), 48.2 (t, 9C, C-3'), 25.9 (t, 9C, C-2') ppm; MS (ESI) m/z (\%): $958.92(100)[\mathrm{M} / 3+\mathrm{Na}]^{+}$; anal. calcd for $\mathrm{C}_{120} \mathrm{H}_{195} \mathrm{~N}_{39} \mathrm{O}_{39}$ : C, 51.33; H, 7.00; N, 19.45; found: C, 51.54; H, 6.79; N, 19.69 .

Protected nonavalent iminosugar 12: In a similar manner as described in [21] to a solution of $4(57 \mathrm{mg}, 0.22 \mathrm{mmol})$ in $3 \mathrm{~mL}$ of a $2: 1 \mathrm{THF} / \mathrm{H}_{2} \mathrm{O}$ mixture, $\mathrm{CuSO}_{4}(30 \mathrm{~mol} \%, 1.2 \mathrm{mg}$, $0.007 \mathrm{mmol})$, sodium ascorbate $(60 \mathrm{~mol} \%, 2.9 \mathrm{mg}$, $0.014 \mathrm{mmol})$ and 6 (20 mg, $0.024 \mathrm{mmol})$ were added. The reaction mixture was heated in a $\mathrm{MW}$ reactor at $80^{\circ} \mathrm{C}$ for $45 \mathrm{~min}$, until TLC analysis showed the disappearance of the starting material. After filtration through Celite ${ }^{\circledR}$, the solvent was removed under reduced pressure and the crude product was purified by gradient FCC (from $\mathrm{CH}_{2} \mathrm{Cl}_{2} / \mathrm{MeOH}$ 10:1 to $\mathrm{CH}_{2} \mathrm{Cl}_{2} / \mathrm{MeOH}$ 1:1) and then by size exclusion chromatography, employing Sephadex LH-20 ${ }^{\circledR}$ resin and eluting with $\mathrm{MeOH}$, to afford pure
$12(67 \mathrm{mg}, 0.021 \mathrm{mmol}, 92 \%)$ as a pale yellow oil. $R_{\mathrm{f}} 0.29$ $\left(\mathrm{CH}_{2} \mathrm{Cl}_{2} / \mathrm{MeOH} 1: 1\right) ;[\alpha]_{\mathrm{D}}{ }^{29}+4.18\left(c 0.70, \mathrm{CHCl}_{3}\right) ;{ }^{1} \mathrm{H} \mathrm{NMR}$ $\left(400 \mathrm{MHz} \mathrm{CDCl}_{3}\right) \delta 8.14(\mathrm{~s}, 3 \mathrm{H}, \mathrm{Ar}), 7.72$ (s, 9H, H-triazole), $7.11(\mathrm{~s}, 3 \mathrm{H}, \mathrm{NH}), 4.56\left(\mathrm{~s}, 18 \mathrm{H}, \mathrm{OCH}_{2}\right.$-triazole $), 4.38(\mathrm{t}, J=6.4$ $\mathrm{Hz}, 18 \mathrm{H}, 3$ '-H), 4.24 (q, $J=5.4 \mathrm{~Hz}, 9 \mathrm{H}, 3-\mathrm{H}), 3.96$ (t, $J=4.9$ $\mathrm{Hz}, 9 \mathrm{H}, 4-\mathrm{H}), 3.89-3.85\left(\mathrm{~m}, 27 \mathrm{H}, 5-\mathrm{H}+\mathrm{OCH}_{2} \mathrm{CNH}\right)$, 2.60-2.43 (m, 27H, 2-H + 1'-Ha), 2.82-2.51 (m, 27H, 6-H + 1'-Hb), 1.99-1.95 (m, 18H, 2'-H), 1.43 (s, 27H, Me), 1.35 (s, 27H, Me) ppm; $\left.{ }^{13} \mathrm{C} \mathrm{NMR} \mathrm{(100} \mathrm{MHz,} \mathrm{CDCl}_{3}\right) \delta 166.5(\mathrm{~s}, 3 \mathrm{C}$, $\mathrm{C}=\mathrm{O}$ ), 144.4 (s, 9C, C-triazole), 135.6 (s, 3C, Ar), 128.6 (d, 3C, Ar), 123.7 (d, 9C, C-triazole), 109,0 (s, 9C, acetal), 77.5 (d, 9C, $\mathrm{C}-4), 72.3(\mathrm{~d}, 9 \mathrm{C}, \mathrm{C}-3), 68.4\left(\mathrm{t}, 9 \mathrm{C}, \mathrm{OCH}_{2} \mathrm{CNH}\right), 68.1$ (d, 9C, $\mathrm{C}-5), 64.7$ (t, 9C, $\mathrm{OCH}_{2}$-triazole), $60.6\left(\mathrm{~s}, 3 \mathrm{C}, \mathrm{OCH}_{2} \mathrm{CNH}\right)$, 56.1 (t, 9C, C-1'), 54.7 (t, 9C, C-2), 53.4 (t, 9C, C-6), 47.8 (t, 9C, C-3'), 28.3 (q, 9C, Me), 27.2 (t, 9C, C-2'), 26.4 (q, 9C, Me) ppm; MS (ESI) $m / z(\%): 1078.53(100)[\mathrm{M} / 3+\mathrm{Na}]^{+}$; IR $\left(\mathrm{CDCl}_{3}\right): v$ 3346, 2989, 2941, 2823, 1663, 1517, 1467, 1382, 1242, 1090, $1057 \mathrm{~cm}^{-1}$; anal. calcd for $\mathrm{C}_{147} \mathrm{H}_{231} \mathrm{~N}_{39} \mathrm{O}_{39}$ : C, 55.72; H, 7.35; N, 17.24; found: C, 55.44; H, 7.69; N, 16.99.

Hydrochloride salt of polyhydroxylated nonavalent iminosugars 11·HCl: To a solution of $\mathbf{1 2}(60 \mathrm{mg}, 0.019 \mathrm{mmol})$ in $7 \mathrm{~mL}$ of methanol, $0.20 \mathrm{~mL}$ of $\mathrm{HCl} 1 \mathrm{M}$ were added and the mixture was stirred at room temperature for 16 hours, until a TLC analysis attested the disappearance of the starting material. The solvent was removed under reduced pressure and the crude product was purified by size exclusion chromatography, employing Sephadex LH-20 ${ }^{\circledR}$ resin and eluting with $\mathrm{H}_{2} \mathrm{O}$, to afford pure hydrochloride salt of $11(55 \mathrm{mg}, 0.019 \mathrm{mmol}$, $100 \%)$ as a waxy solid; $[\alpha]_{\mathrm{D}}{ }^{29}=-13.50\left(\right.$ c 2.30, $\left.\mathrm{H}_{2} \mathrm{O}\right)$; ${ }^{1} \mathrm{H}$ NMR (400 MHz, D $\left.2 \mathrm{O}\right) \delta 7.91$ (s, 3H, Ar), 7.90 (s, 9H, H-triazole), 4.49 (s, $18 \mathrm{H}, \mathrm{OCH}_{2}$-triazole), $4.36(\mathrm{t}, J=6.6 \mathrm{~Hz}$, $18 \mathrm{H}, 3$ '-H), 4.08-4.05 (m, 9H, 3-H), 3.94 (td, $J=7.6,3.7 \mathrm{~Hz}$, 9H, 4-H), 3.79 (s, $\left.18 \mathrm{H}, \mathrm{OCH}_{2} \mathrm{CNH}\right), 3.61$ (br s, 9H, 5-H), $3.25-3.21(\mathrm{~m}, 9 \mathrm{H}), 3.14$ (br s, 9H), 3.03-3.00 (m, 27H), 2.81 (br s, 9H), 2.26-2.17 (m, 18H, 2'-H) ppm; ${ }^{13} \mathrm{C} \mathrm{NMR}$ $\left(100 \mathrm{MHz}, \mathrm{D}_{2} \mathrm{O}\right) \delta 168.5(\mathrm{~s}, 3 \mathrm{C}, \mathrm{C}=\mathrm{O}), 144.0(\mathrm{~s}, 9 \mathrm{C}$, C-triazole), 135.2 (s, 3C, Ar), 129.0 (d, 3C, Ar), 125.3 (d, 9C, C-triazole), 70.4 (d, 9C, C-4), 67.3 (d, 9C, $\left.\mathrm{OCH}_{2} \mathrm{CNH}\right), 65.4$ (d, 9C, C-3), 64.9 (t, 9C, C-5), 63.4 (t, 9C, $\mathrm{OCH}_{2}$-triazole), 60.7 (s, $3 \mathrm{C}, \mathrm{OCH}_{2} \mathrm{CNH}$ ), 53.7 (t, 27C, C-1' + C-2 + C-6), 47.3 (t, 9C, C-3'), 24.4 (t, 9C, C-2') ppm; MS (ESI) $m / z$ (\%): 936.57 (100) $[\mathrm{M} / 3+\mathrm{H}]^{+}$.

Protected monovalent iminosugar 14: Analogously as described in [21] to a solution of $4(49 \mathrm{mg}, 0.190 \mathrm{mmol})$ in $3 \mathrm{~mL}$ of a $2: 1 \mathrm{THF} / \mathrm{H}_{2} \mathrm{O}$ mixture, $\mathrm{CuSO}_{4}(30 \mathrm{~mol} \%, 9.1 \mathrm{mg}$, $0.057 \mathrm{mmol})$, sodium ascorbate $(60 \mathrm{~mol} \%, 23 \mathrm{mg}$, $0.114 \mathrm{mmol})$ and $13(12 \mathrm{mg}, 0.220 \mathrm{mmol})$ were added. The reaction mixture was stirred at room temperature for $16 \mathrm{~h}$, until TLC analysis showed the disappearance of the starting material. 
After filtration through Celite ${ }^{\circledR}$, the solvent was removed under reduced pressure and the crude product was purified by gradient FCC (from $\mathrm{CH}_{2} \mathrm{Cl}_{2} / \mathrm{MeOH}$ 20:1 to $\mathrm{CH}_{2} \mathrm{Cl}_{2} / \mathrm{MeOH} / \mathrm{NH}_{4} \mathrm{OH} 6 \%$ 10:1:0.2) affording pure 14 (57 $\mathrm{mg}, 0.183 \mathrm{mmol}, 96 \%)$ as a pale yellow oil. $R_{\mathrm{f}} 0.88\left(\mathrm{CH}_{2} \mathrm{Cl}_{2} / \mathrm{MeOH} / \mathrm{NH}_{4} \mathrm{OH}\right.$ 6\% 10:1:0.2); $[\alpha]_{\mathrm{D}}{ }^{28}-13.36$ (c 1.25, MeOH); ${ }^{1} \mathrm{H}$ NMR (400 MHz, $\left.\mathrm{CD}_{3} \mathrm{OD}\right) \delta$ 7.91 (s, 1H, H-triazole), 4.48-4.42 (m, 2H, 3'-H), 4.28 (dd, $J=$ $8.8,3.9 \mathrm{~Hz}, 1 \mathrm{H}, 3-\mathrm{H}), 3.93\left(\mathrm{~s}, 2 \mathrm{H}, \mathrm{CH}_{2} \mathrm{NH}_{2}\right), 3.86-3.78(\mathrm{~m}, 2 \mathrm{H}$, $4-\mathrm{H}+5-\mathrm{H}), 2.87(\mathrm{dd}, J=12.2,3.1 \mathrm{~Hz}, 1 \mathrm{H}, 2-\mathrm{Ha}), 2.70-2.64$ (m, 1H, 6-Ha), 2.51-2.43 (m, 1H, 2-Hb), 2.40-2.30 (m, 2H, 1'-H), 2.11-2.03 (m, 3H, 6-Hb + 2'-H), 1.48 (s, 3H, Me), 1.33 (s, 3H, Me) ppm; ${ }^{13} \mathrm{C}$ NMR (100 MHz, CD 3 OD) $\delta 146.8(\mathrm{~s}$, C-triazole), 122.6 (d, C-triazole), 108.7 (s, acetal), 78.7 (d, C-4), 73.1 (d, C-3), 69.0 (d, C-5), 56.0 (t, C-6), 53.7 (t, C-2), 53.5 (t, C-1'), 47.7 (t, C-3'), 35.8 (t, $\left.\mathrm{CH}_{2} \mathrm{NH}_{2}\right), 27.2$ (q, Me), 26.9 (t, C-2'), 25.2 (q, Me) ppm; MS (ESI) $m / z$ (\%): 312.17 (100) $[\mathrm{M}+\mathrm{H}]^{+}$; IR $(\mathrm{MeOH}): v 3419,3305,3146,2994,2808$, $1469,1422,1381,1106,1062 \mathrm{~cm}^{-1}$; anal. calcd for $\mathrm{C}_{14} \mathrm{H}_{25} \mathrm{~N}_{5} \mathrm{O}_{3}$ : C, 54.00; H, 8.09; N, 22.49; found: C, 55.88; $\mathrm{H}$, $8.15 ; \mathrm{N}, 22.81$.

Deprotected monovalent iminosugar 15: In a similar manner as described in [25] a solution of $\mathbf{1 4}(24 \mathrm{mg}, 0.077 \mathrm{mmol})$ in $\mathrm{MeOH}(3 \mathrm{~mL}$ ) was left stirring with $1 \mathrm{M} \mathrm{HCl}$ ( 7 drops) at room temperature for $16 \mathrm{~h}$. The crude mixture was concentrated to yield the hydrochloride salt of $\mathbf{1 5}$. The corresponding free amine was obtained by passing the hydrochloride salt through DOWEX 50XW8-100 ion-exchange resin. Elution with 6\% $\mathrm{NH}_{4} \mathrm{OH}$ afforded the free base 15 (16 mg, $\left.0.059 \mathrm{mmol}, 77 \%\right)$. $[\alpha]_{\mathrm{D}}{ }^{24}-11.43$ (c 0.70, MeOH); ${ }^{1} \mathrm{H}$ NMR (400 MHz, $\left.\mathrm{CD}_{3} \mathrm{OD}\right) \delta$ 7.91 (s, 1H, H-triazole), 4.42-4.34 (m, 2H, 3'-H), 3.97 (s, 2H, $\left.\mathrm{CH}_{2} \mathrm{NH}_{2}\right), 3.80(\mathrm{dt}, J=5.7,2.9 \mathrm{~Hz}, 1 \mathrm{H}, 3-\mathrm{H}), 3.68(\mathrm{td}$, $J=7.9,4.1 \mathrm{~Hz}, 1 \mathrm{H}, 4-\mathrm{H}), 3.30(\mathrm{~d}, J=4.4 \mathrm{~Hz}, 1 \mathrm{H}, 5-\mathrm{H})$, 2.70-2.59 (m, 2H, 2-Ha + 6-Ha), 2.31-2.17 (m, 3H, 2-Hb + $\left.1^{\prime}-\mathrm{H}\right), 2.03-1.93\left(\mathrm{~m}, 3 \mathrm{H}, 6-\mathrm{Hb}+2{ }^{\prime}-\mathrm{H}\right) \mathrm{ppm} ;{ }^{13} \mathrm{C}$ NMR (50 $\left.\mathrm{MHz}, \mathrm{CD}_{3} \mathrm{OD}\right) \delta 144.1$ (s, C-triazole), 123.3 (d, C-triazole), 73.9 (d, C-4), 68.3 (d, C-5), 67.9 (d, C-3), 56.5 (t, C-6), 56.1 (t, C-2), 53.7 (t, C-1'), 47.9 (t, C-3'), 35.2 (t, $\left.\mathrm{CH}_{2} \mathrm{NH}_{2}\right), 26.9$ (t, C-2') ppm; MS (ESI) m/z (\%): 293.87 (100) [M + Na] ${ }^{+}$; anal. calcd for $\mathrm{C}_{11} \mathrm{H}_{21} \mathrm{~N}_{5} \mathrm{O}_{3}$ : C, 48.70; $\mathrm{H}, 7.80 ; \mathrm{N}, 25.81$; found: $\mathrm{C}$, 48.49; H, 7.71; N, 26.19.

\section{Supporting Information}

\section{Supporting Information File 1}

Characterization data, ${ }^{1} \mathrm{H}$ NMR and ${ }^{13} \mathrm{C}$ NMR spectra of synthesized compounds and $\mathrm{IC}_{50}$ graphics of compounds $\mathbf{1 1} \cdot \mathrm{HCl}$ and $\mathbf{1 5}$.

[http://www.beilstein-journals.org/bjoc/content/ supplementary/1860-5397-11-282-S1.pdf]

\section{Acknowledgements}

We thank the Italian Ministry of Health and Regione Toscana (Ricerca Finalizzata-2011-02347694), MIUR-Italy (PRIN 2010-2011, 2010L9SH3K 006) and the Ministerio de Economía y Competitividad (Spain, CTQ 2012-31247) for financial support. We also thank Dr. Amelia Morrone and Dr. Serena Catarzi for biological evaluation towards human lysosomal enzymes.

\section{References}

1. Stütz, A. E., Ed. Iminosugars as Glycosidase Inhibitors: Nojirimycin and Beyond; Wiley-VCH: New York, 1999.

2. Compain, P.; Martin, O. R., Eds. Iminosugars: from Synthesis to Therapeutic Applications; Wiley VCH: New York, 2007.

3. Choi, S.-K., Ed. Synthetic multivalent molecules: concepts and biomedical applications; John Wiley \& Sons, Inc.: Hoboken, New Jersey, 2004.

4. Johns, B. A.; Johnson, C. R. Tetrahedron Lett. 1998, 39, 749-752. doi:10.1016/S0040-4039(97)10616-5

5. Lohse, A.; Jensen, K. B.; Lundgren, K.; Bols, M. Bioorg. Med. Chem. 1999, 7, 1965-1971. doi:10.1016/S0968-0896(99)00116-9

6. Wennekes, T.; Van den Berg, R. J. B. H. N.; Bonger, K. M.; Donker-Koopman, W. E.; Ghisaidoobe, A.; van der Marel, G. A.; Strijland, A.; Aerts, J. M. F. G.; Overkleeft, H. S. Tetrahedron: Asymmetry 2009, 20, 836-846. doi:10.1016/j.tetasy.2009.02.043

7. Diot, J.; García-Moreno, M. I.; Gouin, S. G.; Ortiz Mellet, C.; Haupt, K.; Kovensky, J. Org. Biomol. Chem. 2009, 7, 357-363. doi:10.1039/B815408B

8. Compain, P.; Bodlenner, A. ChemBioChem 2014, 15, 1239-1251. doi:10.1002/cbic.201402026

9. Zelli, R.; Longevial, J.-F.; Dumy, P.; Marra, A. New J. Chem. 2015, 39, 5050-5074. doi:10.1039/C5NJ00462D

10. Gouin, S. G. Chem. - Eur. J. 2014, 20, 11616-11628. doi:10.1002/chem.201402537

11. Compain, P.; Decroocq, C.; lehl, J.; Holler, M.; Hazelard, D.; Mena-Barragán, T.; Ortiz Mellet, C.; Nierengarten, J.-F. Angew. Chem., Int. Ed. 2010, 49, 5753-5756. doi:10.1002/anie.201002802

12. Decroocq, C.; Rodríguez-Lucena, D.; Russo, V.; Mena-Barragán, T.; Ortiz Mellet, C.; Compain, P. Chem. - Eur. J. 2011, 17, 13825-13831. doi:10.1002/chem.201102266

13. Decroocq, C.; Joosten, A.; Sergent, R.; Mena-Barragán, T.; Ortiz Mellet, C.; Compain, P. ChemBioChem 2013, 14, 2038-2049. doi:10.1002/cbic.201300283

14. Brissonnet, Y.; Ortiz Mellet, C.; Morandat, S.; Garcia Moreno, M. I.; Deniaud, D.; Matthews, S. E.; Vidal, S.; Šesták, S.; El Kirat, K.; Gouin, S. G. J. Am. Chem. Soc. 2013, 135, 18427-18435. doi:10.1021/ja406931w

15. Bonduelle, C.; Huang, J.; Mena-Barragán, T.; Ortiz Mellet, C.; Decroocq, C.; Etamé, E.; Heise, A.; Compain, P.; Lecommandoux, S. Chem. Commun. 2014, 50, 3350-3352. doi:10.1039/c3cc48190e

16. Decroocq, C.; Rodríguez-Lucena, D.; Ikeda, K.; Asano, N.; Compain, P. ChemBioChem 2012, 13, 661-664. doi:10.1002/cbic.201200005

17. Joosten, A.; Decroocq, C.; de Sousa, J.; Schneider, J. P.; Etamé, E.; Bodlenner, A.; Butters, T. D.; Compain, P. ChemBioChem 2014, 15 , 309-319. doi:10.1002/cbic.201300442 
18. Compain, P.; Decroocq, C.; Joosten, A.; de Sousa, J.;

Rodríguez-Lucena, D.; Butters, T. D.; Bertrand, J.; Clément, R.; Boinot, C.; Becq, F.; Norez, C. ChemBioChem 2013, 14, 2050-2058. doi:10.1002/cbic.201300312

19. Marradi, M.; Cicchi, S.; Sansone, F.; Casnati, A.; Goti, A. Beilstein J. Org. Chem. 2012, 8, 951-957. doi:10.3762/bjoc.8.107

20. Cardona, F.; Isoldi, G.; Sansone, F.; Casnati, A.; Goti, A. J. Org. Chem. 2012, 77, 6980-6988. doi:10.1021/jo301155p

21. D’Adamio, G.; Parmeggiani, C.; Goti, A.; Moreno-Vargas, A. J.; Moreno-Clavijo, E.; Robina, I.; Cardona, F. Org. Biomol. Chem. 2014, 12, 6250-6266. doi:10.1039/C4OB01117A

22. Moreno-Clavijo, E.; Carmona, A. T.; Moreno-Vargas, A. J.; Molina, L.; Wright, D. W.; Davies, G. J.; Robina, I. Eur. J. Org. Chem. 2013, 7328-7336. doi:10.1002/ejoc.201300878

23. Tu, Z.; Lin, Y.-N.; Lin, C.-H. Chem. Soc. Rev. 2013, 42, 4459-4475. doi:10.1039/c3cs60056d

24. Matassini, C.; Mirabella, S.; Goti, A.; Cardona, F. Eur. J. Org. Chem. 2012, 3920-3924. doi:10.1002/ejoc.201200587

25. Matassini, C.; Mirabella, S.; Ferhati, X.; Faggi, C.; Robina, I.; Goti, A.; Moreno-Clavijo, E.; Moreno-Vargas, A. J.; Cardona, F. Eur. J. Org. Chem. 2014, 5419-5432. doi:10.1002/ejoc.201402427

26. Ichikawa, Y.; Igarashi, Y.; Ichikawa, M.; Suhara, Y. J. Am. Chem. Soc. 1998, 120, 3007-3018. doi:10.1021/ja973443k

27. Legler, G.; Stütz, A. E.; Immich, H. Carbohydr. Res. 1995, 272, 17-30. doi:10.1016/0008-6215(95)00032-O

28. Parmeggiani, C.; Catarzi, S.; Matassini, C.; D'Adamio, G.; Morrone, A.; Goti, A.; Paoli, P.; Cardona, F. ChemBioChem 2015, 16, 2054-2064. doi:10.1002/cbic.201500292

29. Kolb, H. C.; Finn, M. G.; Sharpless, K. B. Angew. Chem., Int. Ed. 2001, 40, 2004-2021. doi:10.1002/1521-3773(20010601)40:11<2004::AID-ANIE2004>3.0.CO ;2-5

30. Rostovtsev, V. C.; Green, L. G.; Fokin, V. V.; Sharpless, K. B. Angew. Chem., Int. Ed. 2002, 41, 2596-2599. doi:10.1002/1521-3773(20020715)41:14<2596::AID-ANIE2596>3.0.CO ;2-4

31. Tornøe, C. W.; Christensen, C.; Meldal, M. J. Org. Chem. 2002, 67, 3057-3064. doi:10.1021/jo011148j

32. Meldal, M.; Tornøe, C. W. Chem. Rev. 2008, 108, 2952-3015. doi:10.1021/cr0783479

33. Chen, F.-E.; Zhao, J.-F.; Xiong, F.-J.; Xie, B.; Zhang, P. Carbohydr. Res. 2007, 342, 2461-2464. doi:10.1016/j.carres.2007.06.029

34. Vercillo, O. E.; Andrade, C. K. Z.; Wessjohann, L. A. Org. Lett. 2008, 10, 205-208. doi:10.1021/ol702521g

35. Papp, I.; Dernedde, J.; Enders, S.; Haag, R. Chem. Commun. 2008, 5851-5853. doi:10.1039/b813414f

36. Gavale, K. S.; Chavan, S. R.; Khan, A.; Joshi, R.; Dhavale, D. D. Org. Biomol. Chem. 2015, 13, 6634-6646. doi:10.1039/C5OB00668F See for comparison, $\mathrm{IC}_{50}$ values for known amyloglucosidase inhibitors DNJ and Miglitol are $1.7 \mu \mathrm{M}$ and $24 \mu \mathrm{M}$, respectively.

37. Kanfar, N.; Bartolami, E.; Zelli, R.; Marra, A.; Winum, J.-Y.; Ulrich, S.; Dumy, P. Org. Biomol. Chem. 2015, 13, 9894-9906. doi:10.1039/C5OB01405K

38. Brissonet, Y.; Ladevèze, S.; Tezé, D.; Fabre, E.; Deniaud, D.; Daligault, F.; Tellier, C.; Šesták, S.; Remaud-Simeon, M.; Potocki-Veronese, G.; Gouin, S. G. Bioconjugate Chem. 2015, 26 , 766-772. doi:10.1021/acs.bioconjchem.5b00081

39. Rivera-Colón, Y.; Schutsky, E. K.; Kita, A. Z.; Garman, S. G. J. Mol. Biol. 2012, 423, 736-751. doi:10.1016/j.jmb.2012.08.020

\section{License and Terms}

This is an Open Access article under the terms of the Creative Commons Attribution License

(http://creativecommons.org/licenses/by/2.0), which permits unrestricted use, distribution, and reproduction in any medium, provided the original work is properly cited.

The license is subject to the Beilstein Journal of Organic Chemistry terms and conditions:

(http://www.beilstein-journals.org/bjoc)

The definitive version of this article is the electronic one which can be found at: doi:10.3762/bjoc. 11.282 